Arch. Tierz., Dummerstorf 48 (2005) 5, 518-526

Department of Zootechny, Faculty of Veterinary Medicine, Firat University, 23119 Elazig, TURKEY

IBRAHIM SEKER, SELIM KUL and METIN BAYRAKTAR

\title{
Effects of storage period and egg weight of Japanese quail eggs on hatching results (short communication)
}

\author{
Dedicated to Prof. Dr. Peter Horst on the occasion of his $75^{\text {th }}$ birthday
}

\begin{abstract}
This study was undertaken to determine the effects of storage period and egg weight of hatching eggs of Japanese quails on fertility, hatchability results. Eggs were obtained 150 females quails, all at 15 weeks of age. A total of 1942 hatching eggs were separated into 3 groups as light-weight (9.50-10.50 g), medium-weight (10.51$11.50 \mathrm{~g})$, and heavy-weight (11.51-12.50 g). Based on storage period, eggs were divided into 5 groups as group 1 (0-3 days), group 2 (4-6 days), group 3 (7-9 days), group 4 (10-12 days), and group 5 (13-15 days).

The influence of storage period on hatchability of fertile eggs and early, middle, and late period embryonic mortality rates was found significant $(\mathrm{P}<0.01)$. The effect of egg weight on fertility rate, hatchability of fertile eggs and early embryonic mortality was significant $(\mathrm{P}<0.05, \mathrm{P}<0.01)$. The significant differences between storage period groups were observed in hatchability of fertile eggs. The differences between egg weight groups for fertility rate, hatchability of fertile eggs and early embryonic mortality was significantly higher in light weight group than the other egg weight groups. Results of this study concluded that a 12 day pre-incubation storage of hatching eggs of Japanese quails did not appreciably affect hatching parameters. Use of medium or heavy weight eggs for hatching may reduce early embryonic mortality rate.
\end{abstract}

Key Words: storage period, egg weight, hatchability, embryonic mortality, quail

\section{Zusammenfassung}

Titel der Arbeit: Einfluss von Lagerungsdauer und Eigewicht von Wachteleiern auf die Brutergebnisse (Kurzmitteilung)

In vorliegender Studie soll der Einfluss der Lagerungsdauer und des Eigewichtes von Wachteleiern auf die Brutergebnisse untersucht werden. Die Eier stammen von 15 Wochen alten 150 Hennen. Insgesamt 1942 Bruteier wurden entsprechend ihren Gewichten in drei Gruppen (9,50-10,50 g; 10,51-11,50 und 11,51-12,50 g) und diese wiederum in fünf Untergruppen mit einer Lagerdauer von 0-3; 4-6; 7-9; 10-12 und 13-15 Tagen eingeteilt.

Es konnte ein signifikanter $(\mathrm{p}<0,01)$ Einfluss der Lagerungsdauer auf die Befruchtungsrate, auf das Schlupfergebnis und die embryonale Mortalität während der gesamten Brutdauer nachgewiesen werden. Gleiches galt auch für den Einfluss des Eigewichtes auf das Befruchtungs- sowie das Schlupfergebnis, während das für die embryonale Mortalität nur für den ersten Brutabschnitt zutraf. Signifikante Unterschiede ergaben sich für den Einfluss der Lagerungszeit auf das Schlupfergebnis befruchteter Eier und die embryonale Mortalität in der frühen Brutperiode. Die schlechtesten Ergebnisse erzielten die Eier mit den geringsten Gewichten gegenüber den Eiern der schwereren Gruppen. Die Untersuchungen ergaben, dass eine Lagerzeit von bis 12 Tagen die Schlupfergebnisse nur unwesentlich beeinträchtigten und höhere Eigewichte die embryonale Mortalität verringerten.

Schlüsselwörter: Eilagerungsdauer, Eigewicht, Schlupfrate, embryonale Mortalität, Wachtel

\section{Introduction}

The attention of numerous researchers has been focused on the relationship between egg weight and time of storage and the effect of these on hatching success and chick quality for many years (WILSON, 1991). A number of papers dealing with the 
problem have drawn from research on poultry species such as hens and turkeys (SHANAWANY, 1984; YANNAKOPOULOS and TSERVENI-GOUSI, 1987; PINGEL et al., 1989). On the other hand, there is a paucity of information on breeding the quail, a species which has recently gained in popularity and is bred in many countries.

Fertility rate, hatchability of all eggs set or fertile eggs, and embryonic mortality rate in poultry are influenced by many factors including male/female ratio, genetic, age of parents, nutrition, storage conditions and period of eggs, quality and weight of eggs, and incubation conditions (NARAHARI et. al., 1988; BRAH et al., 2001; ALTAN et al., 2002). Some researchers reported that body weight and egg weight are correlated (OZCELIK and OZBEY, 1993; ADEDOKIN and SONAIYA, 2002) and by selection the body weight could be increasing (MIELENZ et al., 2000; SHAHIN et al., 2000; BRAH et al., 2001). Optimization of storage period and conditions of hatching eggs are essential for hatching industry.

Regardless of under how optimum conditions the eggs are stored; hatching success rate of incubated eggs stored more than a week will decrease (MAYES and TAKEBALLI, 1984). Since commercial hatching establishments generally receive eggs few times a week, eggs are rarely stored more than a week (ALTAN et al., 2002). However, in poultry breeding establishments, it may be necessary to store eggs longer than a week to produce sufficient numbers of offspring's, which is necessary for pedigree poultry production (SCHOLTYSSEK, 1987).

The effects of pre incubational egg storage on embryonic viability depend on storage time, environmental conditions, hen age, and strain (BRAKE et al., 1997). Some researchers reported that the decrease in viability of the embryo may be caused by changes in the embryo or by changes in certain physical aspects of the egg, namely albumen $\mathrm{pH}$ (MEIJERHOF, 1994). Pre incubational egg storage leads to morphological changes in the blastoderm and malformations in the embryo (ARORA and KOSIN, 1966).

There are research reports indicating that extended storage cause decreases in hatchability of incubated eggs (SUKSUPATH and TANPIPAT, 1991), hatchability of fertile eggs (SREENIVASAIAH and RAMAPPA, 1988), and increase embryonic mortality rates (SCOTT and MACKENZIE, 1993). Furthermore, conflicting results have been reported regarding the effects of short-term storage on hatching performance (MAYES and TAKEBALLI, 1984).

Optimum hatching results can be obtained from eggs of certain weight (OZCELIK and OZBEY, 2004). Some researchers reported that hatchability of all eggs set was higher in heavy eggs than in light eggs (SERGEEVA, 1984). SACHDEV et al. (1985) reported that hatchability of fertile eggs and fertility rate were found higher in heavy hen eggs (10.1-11.0 g) than in lightweight eggs (7.01-8.90 g). Similarly, ALTAN et al. (1995) and BRAH et al. (1999) reported that fertility rate, hatchability of all eggs set or fertile eggs were higher in heavy weight eggs compared to light eggs.

UDDIN et al. (1994) studied effect of egg weight (8.59, 9.52, $10.56 \mathrm{~g})$ and storage (1, 4, 7, 10 days) on hatching parameters. Their results showed that except for fertility, all parameters were affected by egg weight $(\mathrm{P}<0.05)$. No meaningful relation was found between egg weight and length of storage. A negative correlation between egg weight and fertility rate was also detected. The researchers concluded that medium size eggs (9.1-10.0 g) can be stored in any season for 4 to 7 days for a successful hatching. 
Objective of this study was to evaluate effects of egg weight and storage period of Japanese quail hatching eggs on fertility rate, hatchability of fertile eggs, and embryo mortality.

\section{Materials and Methods}

A total of 1942 Japanese quail eggs were used for this study. Eggs were obtained 150 female quails, all at 15 weeks of age. The birds were housed as 1 male/ 3 female per cage of 30x30 cm at Quail Research unit of the Department of Zootechny, Faculty of Veterinary Medicine, Firat University. The Japanese quail were raised in floor pens and fed conventional starter and grower diets until they reached 6 wk of age. A standard layer diet (20\% protein and 3.0\% calcium) were given ad libitum. Water was available for ad libitum consumption and natural daylight was supplemented with artificial light to give an 18-h photoperiod.

Eggs were collected every day and at the same time (at 15:00), during 15 days. After the eggs were collected they were immediately weighted by using a digital scale within 1 hour and then divided into 3 groups based on their weights as light weight group (9.50-10.50 g), medium weight group (10.51-11.50 g), and heavy weight group (11.51-12.50 g). The eggs were stored at $9-12{ }^{\circ} \mathrm{C}$ with $70-75 \% \mathrm{RH}$ for up to 15 days before incubation. Based on length of storage period, the eggs were divided into 5 groups as storage group 1 (0-3 days), storage group 2 (4-6 days), storage group 3 (7-9 days), storage group 4 (10-12 days), and storage group 5 (13-15 days). The eggs were turned manually twice a day at 6 hours' interval at 8.00 A.M. and 2.00 P.M. keeping at $45^{\circ}$ angle in both the directions. Eggs were fumigated for 20 min with formaldehyde gas in the incubator.

In this study, CIMUKA hatcher with 3000 quail eggs capacity was used. The incubation temperature for the first 15 days of incubation was $37.7^{\circ} \mathrm{C}$, after which it was reduced to $37.5^{\circ} \mathrm{C}$ for the rest of the incubation period. The relative humidity of 55 to $60 \%$ for the first 15 days of incubation and 70 to $75 \%$ for the rest period were maintained properly. Automatic turning devices were used to turn the eggs 6 times in 24 hours up to the $15^{\text {th }}$ day of incubation. Air circulation and the temperature were controlled automatically as well. The eggs were transferred to the hatching trays and arranged separately. The eggs candled on the $6^{\text {th }}$ days of incubation to detect the fertile eggs and dead embryos. The embryos of fertile eggs showing the evidence of retarded development and no movement on candling were considered as dead-embryos which were subsequently confirmed. At the end of hatch all chicks were removed. Unhatched eggs were opened, examined macroscopically, and assigned to one of the following categories: mid-dead (7-15), late-dead (after 16 d). Embryonic mortality rates in the fertile eggs were calculated in percent. Hatching parameters were calculated using the following formulas:

Fertility rate $(\%)=($ Numbers of fertile eggs/Total numbers of eggs $) \times 100$ Hatchability of fertile eggs $(\%)=($ Numbers of chicks/Total numbers of fertile eggs) $\times 100$

All data in percentages were transformed using arc sin transformations ( $\operatorname{arc} \sin \sqrt{\% P}$ ) prior to analysis (DUZGUNES et al., 1987). However, while descriptive values of related to results were presented in this study non transform data were used. To determine the effects of storage period and egg weight on fertility rate, hatchability of fertile eggs, and embryonic mortality rates analysis of variance (ANOVA) were performed by using non transform data. If significant differences $(\mathrm{P}<0.05)$ were found 
by ANOVA, means of fertility rate, hatchability, and embryo mortality data were separated using Duncan's Multiple Range Test (SNEDECOR and COCHRAN, 1980). SPSS analysis software was used for analysis (SPSS FOR WINDOWS, 1999).

\section{Results}

The statistical analysis results of effects of storage period and egg weight on fertility rate and hatchability results and differences between storage period groups and between egg weight groups were presented in Table 1a-b.

The influence of storage period on hatchability of fertile eggs and early, middle, and late period embryonic mortality rates was found significant $(\mathrm{P}<0.01)$. The effect of egg weight on fertility rate, hatchability of fertile eggs and early embryonic mortality was significant $(\mathrm{P}<0.05, \mathrm{P}<0.01)$. The effect of interaction between storage period and egg weight was found significant $(\mathrm{P}<0.05, \mathrm{P}<0.01)$ for hatchability of fertile eggs, early and late embryonic mortality rates.

Table 1a

Effect of pre-incubation storage period and egg weight on hatching results of Japanese quail eggs (Übersicht zu Lagerungsdauer und Eigewicht sowie Schlupfergebnisse von Wachteleiern)

\begin{tabular}{|c|c|c|c|c|c|}
\hline $\begin{array}{l}\text { Storage period } \\
\text { groups }\end{array}$ & $\begin{array}{l}\text { Egg weight } \\
\text { groups }\end{array}$ & $\begin{array}{c}\text { Total } \\
\text { numbers of } \\
\text { eggs }\end{array}$ & $\begin{array}{c}\text { Egg } \\
\text { weight } \\
\text { (g) } \\
\bar{X} \pm \mathrm{S} \bar{X}\end{array}$ & $\begin{array}{c}\text { Numbers } \\
\text { of fertile } \\
\text { eggs }\end{array}$ & $\begin{array}{c}\text { Numbers of } \\
\text { hatched chicks }\end{array}$ \\
\hline 1 & $1(9.50-10.50 \mathrm{~g})$ & 38 & $9.79 \quad 0.15$ & 30 & 28 \\
\hline \multirow{2}{*}{$(\leq 3 \mathrm{~d})$} & 2 (10.51-11.50 g) & 146 & $11.04 \quad 0.02$ & 114 & 99 \\
\hline & 3 (11.51-12.50 g) & 152 & $12.05 \quad 0.04$ & 122 & 111 \\
\hline Total & & 336 & $11.35 \quad 0.05$ & 266 & 238 \\
\hline 2 & $1(9.50-10.50 \mathrm{~g})$ & 47 & $\begin{array}{ll}9.87 & 0.13\end{array}$ & 36 & 33 \\
\hline \multirow[t]{2}{*}{$(4-6 \mathrm{~d})$} & 2 (10.51-11.50 g) & 151 & $11.05 \quad 0.02$ & 114 & 101 \\
\hline & 3 (11.51-12.50 g) & 138 & $11.96 \quad 0.04$ & 114 & 98 \\
\hline Total & & 336 & $11.26 \quad 0.05$ & 264 & 232 \\
\hline 3 & $1(9.50-10.50 \mathrm{~g})$ & 74 & $9.95 \quad 0.08$ & 54 & 28 \\
\hline \multirow[t]{2}{*}{$(7-9 d)$} & 2 (10.51-11.50 g) & 143 & $10.98 \quad 0.02$ & 111 & 96 \\
\hline & 3 (11.51-12.50 g) & 148 & $12.01 \quad 0.04$ & 119 & 78 \\
\hline Total & & 365 & $11.19 \quad 0.05$ & 284 & 202 \\
\hline 4 & 1 (9.50-10.50 g) & 72 & $9.84 \quad 0.06$ & 40 & 20 \\
\hline \multirow{2}{*}{$(10-12 d)$} & 2 (10.51-11.50 g) & 124 & 11.050 .03 & 83 & 65 \\
\hline & 3 (11.51-12.50 g) & 93 & $12.05 \quad 0.06$ & 73 & 65 \\
\hline Total & & 289 & 11.07 & 196 & 150 \\
\hline 5 & 1 (9.50-10.50 g) & 110 & 9.97 & 71 & 36 \\
\hline \multirow[t]{2}{*}{$(13-15 d)$} & 2 (10.51-11.50 g) & 242 & 11.03 & 196 & 85 \\
\hline & 3 (11.51-12.50 g) & 264 & 12.05 & 204 & 116 \\
\hline Total & & 616 & 11.28 & 471 & 237 \\
\hline \multirow[t]{3}{*}{ Total } & 1 (9.50-10.50 g) & 341 & 9.910 .04 & 231 & 145 \\
\hline & 2 (10.51-11.50 g) & 806 & $11.03 \quad 0.01$ & 618 & 446 \\
\hline & 3 (11.51-12.50 g) & 795 & $12.02 \quad 0.02$ & 632 & 468 \\
\hline Total & & 1942 & $11.24 \quad 0.02$ & 1481 & 1059 \\
\hline
\end{tabular}

The significant differences between storage period groups were observed in hatchability of fertile eggs. In general, the differences between all the storage period groups were significant for early embryonic mortality rates. The differences between storage period group 1., 2., and 3 and 5 for late embryonic mortality rates were found significant. For late embryonic mortality rates the differences between storage period group 5 and the other storage period groups were significant as well. The differences between egg weight groups for fertility rate, hatchability of fertile eggs and early 
embryonic mortality was significantly higher in light weight group than the other egg weight groups.

The differences between egg weight groups for fertility rate and for hatchability results were not found significant in storage period group 1 and $2(\mathrm{P}>0.05)$. However, the differences between egg weight groups for hatchability results (except for middle embryonic mortality) in storage period group 3, and for hatchability results (except for middle and late embryonic mortality) in storage period group 4 and 5 were found statistically significant $(\mathrm{P}<0.05, \mathrm{P}<0.01)$.

Table $1 \mathrm{~b}$

Effect of pre-incubation storage period and egg weight on hatching results of Japanese quail eggs (Einfluss von Lagerungsdauer und Eigewicht auf Schlupfergebnisse von Wachteln)

\begin{tabular}{|c|c|c|c|c|c|c|}
\hline $\begin{array}{l}\text { Storage period } \\
\text { groups }\end{array}$ & $\begin{array}{l}\text { Egg weight } \\
\text { groups }\end{array}$ & $\begin{array}{l}\text { Fertility } \\
\text { rate } \\
(\%)\end{array}$ & $\begin{array}{c}\text { Hatchability } \\
\text { of fertile } \\
\text { eggs } \\
\text { (\%) }\end{array}$ & $\begin{array}{c}\text { Early } \\
\text { period } \\
\text { embryonic } \\
\text { death (\%) }\end{array}$ & $\begin{array}{c}\text { Middle } \\
\text { period } \\
\text { embryonic } \\
\text { death (\%) }\end{array}$ & $\begin{array}{l}\text { Last period } \\
\text { embryonic } \\
\text { death (\%) }\end{array}$ \\
\hline 1 & $1(9.50-10.50 \mathrm{~g})$ & 78.95 & 93.33 & 6.67 & 0.00 & 0.00 \\
\hline \multirow[t]{2}{*}{$(\leq 3 \mathrm{~d})$} & 2 (10.51-11.50 g) & 78.08 & 86.84 & 6.14 & 2.63 & 4.39 \\
\hline & 3 (11.51-12.50 g) & 80.26 & 90.98 & 2.46 & 2.46 & 4.10 \\
\hline $\mathrm{P}$ & & - & & - & - & - \\
\hline Total & & $79.10^{\mathrm{B}}$ & $90.39^{\mathrm{C}}$ & $5.09^{\mathrm{A}}$ & $1.70^{\mathrm{A}}$ & $2.83^{\mathrm{A}}$ \\
\hline 2 & 1 (9.50-10.50 g) & 76.60 & 91.67 & 2.78 & 2.78 & 2.78 \\
\hline \multirow[t]{2}{*}{$(4-6 d)$} & 2 (10.51-11.50 g) & 75.50 & 88.60 & 4.39 & 4.39 & 2.63 \\
\hline & 3 (11.51-12.50 g) & 82.61 & 85.96 & 8.77 & 2.63 & 2.63 \\
\hline $\mathrm{P}$ & & - & - & - & - & - \\
\hline Total & & $78.23^{\mathrm{B}}$ & $88.74^{\mathrm{C}}$ & $5.31^{\mathrm{A}}$ & $3.27^{\mathrm{A}}$ & $2.68^{\mathrm{A}}$ \\
\hline 3 & $1(9.50-10.50 \mathrm{~g})$ & $72.97^{x}$ & $51.85^{x}$ & $35.19^{y}$ & 5.56 & $7.41^{x}$ \\
\hline \multirow[t]{2}{*}{$(7-9 d)$} & 2 (10.51-11.50 g) & $77.62^{y}$ & $86.49^{y}$ & $8.11^{\mathrm{x}}$ & 1.80 & $3.60^{\mathrm{x}}$ \\
\hline & 3 (11.51-12.50 g) & $80.41^{\mathrm{y}}$ & $65.55^{y}$ & $15.13^{\mathrm{x}}$ & 5.04 & $14.29^{y}$ \\
\hline $\mathrm{P}$ & & $* *$ & $* *$ & $* *$ & - & $* *$ \\
\hline Total & & $77.00^{\mathrm{B}}$ & $67.96^{\mathrm{B}}$ & $19.47^{\mathrm{BC}}$ & $4.13^{\mathrm{A}}$ & $8.43^{\mathrm{A}}$ \\
\hline 4 & $1(9.50-10.50 \mathrm{~g})$ & $55.56^{x}$ & $50.00^{x}$ & $27.50^{y}$ & 17.50 & 5.00 \\
\hline \multirow[t]{2}{*}{$(10-12 \mathrm{~d})$} & 2 (10.51-11.50 g) & $66.94^{x y}$ & $78.31^{\mathrm{y}}$ & $8.43^{x}$ & 7.23 & 6.02 \\
\hline & 3 (11.51-12.50 g) & $78.49^{y}$ & $89.04^{\mathrm{z}}$ & $4.11^{x}$ & 5.48 & 1.37 \\
\hline $\mathrm{P}$ & & $* *$ & $* *$ & $*$ & - & - \\
\hline Total & & $66.99^{\mathrm{A}}$ & $72.45^{\mathrm{B}}$ & $13.35^{\mathrm{AB}}$ & $10.07^{\mathrm{AB}}$ & $4.13^{\mathrm{A}}$ \\
\hline 5 & 1 (9.50-10.50 g) & $64.55^{x}$ & $50.70^{x}$ & $25.35^{y}$ & 8.45 & 15.49 \\
\hline \multirow[t]{2}{*}{$(13-15 d)$} & 2 (10.51-11.50 g) & $80.99^{y}$ & $43.37^{x y}$ & $21.94^{y}$ & 10.71 & 23.98 \\
\hline & 3 (11.51-12.50 g) & $77.27^{\mathrm{y}}$ & $56.86^{\mathrm{y}}$ & $11.27^{\mathrm{x}}$ & 12.25 & 19.61 \\
\hline$P$ & & $* *$ & $*$ & $* *$ & - & - \\
\hline Total & & $74.27^{\mathrm{B}}$ & $50.31^{\mathrm{A}}$ & $19.52^{\mathrm{C}}$ & $10.47^{\mathrm{B}}$ & $19.69^{\mathrm{B}}$ \\
\hline \multirow[t]{3}{*}{ Total } & $1(9.50-10.50 \mathrm{~g})$ & $69.72^{\mathrm{a}}$ & $67.51^{\mathrm{a}}$ & $19.49^{b}$ & 6.86 & 6.14 \\
\hline & 2 (10.51-11.50 g) & $75.83^{\mathrm{b}}$ & $76.72^{\mathrm{b}}$ & $9.80^{\mathrm{a}}$ & 5.35 & 8.13 \\
\hline & 3 (11.51-12.50 g) & $79.81^{\mathrm{b}}$ & $77.68^{\mathrm{b}}$ & $8.35^{\mathrm{a}}$ & 5.57 & 8.40 \\
\hline Total & & 75.12 & 73.97 & 12.55 & 5.93 & 7.55 \\
\hline \multicolumn{2}{|c|}{ Storage period effect } & $* *$ & $* *$ & $* *$ & $* *$ & $* *$ \\
\hline \multicolumn{2}{|c|}{ Egg weight effect } & $* *$ & $* *$ & $*$ & - & - \\
\hline \multicolumn{2}{|c|}{ Storage period x Egg weight effect } & - & $* *$ & $* *$ & - & * \\
\hline
\end{tabular}

In this study, while egg weight increased fertility rate and hatchability of fertile eggs increased but early embryonic mortality decreased. The highest fertility rate (79.81\%) and the lowest hatchability of fertile eggs (67.51\%) were occurred in heavy weight group and light weight group, respectively. Additionally, the highest early embryonic 
mortality rate (19.49\%) was determined in light weight group. While the storage period increased, early and middle embryonic mortality rates increased in all the storage period groups (except for group 4) in contrast, hatchability of fertile eggs reduced in all storage period groups. The lowest hatchability of fertile eggs and the highest embryonic mortality rates for all embryonic periods were determined in storage period group 5 .

\section{Discussion}

Effects of storage period and egg weight on hatching parameters in Japanese quail eggs were evaluated in the present study. Hatchability of incubated eggs significantly was affected by storage period. This rate was calculated as $90.39 \%, 88.74 \%, 67.96 \%$, $72.45 \%$, and $50.31 \%$ for storage groups 1 through 5 respectively. In general, as the storage period extended, hatchability of fertile eggs decreased. This finding was in agreement with results of other previous studies (SUKSUPATH and TANPIPAT, 1991). Similarly, AKINCI, 1996 reported that a pre-incubation storage of hatching eggs longer than 8-10 days because dramatic decreases in hatchability of incubated eggs. Likewise, SREENIVASAIAH and RAMAPPA (1988) reported that dramatic changes occurred in hatchability of fertile eggs after 9 days of storage.

As far as the effect of storage period on embryo mortality rate, significant differences were observed in early and late mortalities. In general, an increase in early and middle mortality was observed in hatching eggs stored longer than 10-12 days. These results are in agreement with results of previous reports (SCOTT and MACKENZIE, 1993).

Another result of the present study was that embryonic mortality, regardless of the developmental stage, was not different between storage groups 1 and 2. Similarly, ALTAN et al. (2002) reported that embryo mortality rate was not affected in hen eggs after storage of $6 \mathrm{~h}, 3$ days or 7 days.

The increasing tendencies of the embryonic mortality with the increasing length of the pre-incubation holding periods are in accordance with the findings of HAMID and SALAH UDDIN (1986). The might be due to increased stickiness of the chicks prior to piping out resulting from the increased evaporative losses of the eggs.

An important parameter evaluated in the present study was the egg weight. Among different weight groups, with the exception of early embryonic mortality, no other parameter was found significantly different. Fertility rates of light, medium, and heavy weight eggs were $69.72 \%, 75.83 \%$, and $79.81 \%$, respectively indicating a trend that fertility may increase as the weight increase. Such a relation was also reported by SACHDEV et al. (1985) and ALTAN et al. (1995) in Japanese quails. Similarly, some other researchers reported a negative correlation between egg weight and fertility rate in Japanese quail eggs stored for various days before incubation (UDDIN et al., 1994). The finding that fertility was significantly affected by egg weight was not also in agreement with results of ESEN and OZCELIK (2002). However, this contradiction might be due to differences in experimental design (e.g. grouping eggs, storage conditions).

In the present study, hatching rate of fertile eggs in egg weight groups was found 67.51\% (light weight group), 76.72\% (medium weight group), and $77.68 \%$ (heavy weight group). Another finding related to the egg weight in this study was that hatchability of fertile eggs increased as the egg weight increased. Similarly, SARICA 
and SOLEY (1995) indicated that the highest hatchability of all eggs set was observed in eggs $\geq 11.6$ g.

Hatchability of fertile eggs was significantly different between egg weight groups in the present study; a trend was seen about increase in the rate by the increase in weight. Similarly, SACHDEV et al. (1985) reported that hatching rate of fertile eggs was higher in heavy weight Japanese quail eggs (10.1-11.0 g) than it was in light weight eggs (7.1-8.9 g).

In the present study, only early embryonic mortality rate was found significantly different among egg weight groups. Early embryonic mortality rates were $19.49 \%$, 9.80\%, and $8.35 \%$ for light, medium, and heavy weight egg groups, respectively. Ratio of light weight group (9.50-10.50 g) was significantly higher than of medium and heavy weight egg groups, indicating early embryonic mortality decrease as the egg weight increase. This situation might be explained because heavy weight eggs have more sufficient nutrients substance to support embryos compare to those of light weight eggs.

This finding was in agreement with the conclusions of ALTAN et al. (1995) and SACHDEV et al. (1985).

\section{Conclusion}

In summary, results of the present study revealed that extended storage of Japanese quail eggs before incubation, especially after 6 days; result in decreases in hatchability of all eggs set or fertile eggs. In addition, the highest embryonic mortality rates occurred in eggs stored for 15 days. The best performance for fertility rate and hatchability of fertile eggs was obtained from eggs stored for 3 days. Optimum fertility rate, hatchability of fertile eggs and early embryonic mortality rate were observed in eggs weighing 11.51-12.50 g.

\section{Acknowledgement}

We would like to thank Dr. Mehmet Calicioglu of Firat University, Faculty of Veterinary Medicine, Department of Food Hygiene and Technology, for his revisions and improvement in the English of the manuscript.

\section{References}

ADEDOKUN, S.A.; SONAIYA, E.B.:

Crossbreeding Nigeria Indigenous with Dahlem Red chickens for improved productivity and adaptability. Arch. Tierz., Dummerstorf 45 (2002) 3, 297-305

AKINCI, Z.:

The effects of pre-incubation warming, storage time and egg position during storage on hatchability. Veterinary Journal of Ankara University. 43 (1996), 259-266

ALTAN, O.; ALTAN, A.; BAYRAKTAR, H.; DEMIRCIOGLU, A.:

Effect of short-term on hatchability and total incubation period of breeder hatching eggs. Turk J. Vet. Anim. Sci. 26 (2002), 447-452

ALTAN, O.; OGUZ, I.; SETTAR, P.:

Effect of egg weight and specific gravity on hatchability and chick weight in Japanese quail. Turkish Journal of Agriculture and Forestry. 19 (1995) 4, 219-222

ARORA, K. L.; KOSIN, I. L.:

Changes in the gross morphological appearance of chicken and turkey blastoderms during preincubation storage. Poult. Sci. 45 (1966), 819-825 
BRAH, G.S.; CHAUDHARY M.L; SANDHU, J.S.:

Direct and correlated responses to selection for 4-week body weight in two lines of Japanese quails. Arch. Tierz., Dummerstorf 44 (2001) 1, 99-108

BRAH, G.S.; SANDHU J.S.; CHAUDHARY, M.L.:

Variance and covariance component analysis of incubational mortality in chickens. Arch. Tierz., Dummerstorf 42 (1999) 3, 295-302

BRAKE, T.J.; WALSH, J.; BENTON, C.E.; PETITTE, J.N.; MEIJERHOF, R.; PENALVA, G.: Egg handling and storage. Poult. Sci. 76 (1997), 144-151

DUZGUNES, O, KESICI, T.; KAVUNCU, O.; GURBUZ, F.:

Research and experimental methods (Arastirma ve deneme metodlari). A.U. Ziraat Fak. Yay., No: 1021, Ankara; 1987, p. 381

ESEN, A.; OZCELIK, M.:

The effect of Age of parents, egg weight and shape index on hatchability in quails. Firat University Journal of Health Sciences. 16 (2002) 1, 19-25

HAMID, M.A., SALAH UDDIN, M.:

Effect of different pre-incubation holding periods on hatchability of different breeds of chicken. Bangladesh Journal of Agricultural Sciences. 13 (1986) 1, 29-33

MAYES, F.J.; TAKEBALLI, M.A.:

Storage of eggs of fowl (Gallus domesticus) before incubation; a review. World's Poult. Sci. J. 40 (1984) 2, 131-140

MEIJERHOF, R.:

Theoretical and empirical studies on temperature and moisture loss of hatching eggs during the preincubation period. Ph.D. dissertation. University of Wageningen, The Netherlands. (1994)

MIELENZ, N.; DITMAR, E.; SCHÜLER, L.:

Effektivität der Zuchtwertschätzung mit transformierten Daten, überprüft mit Mütter-Töchter-Paaren eines Wachstumsexperimentes (Effectiviness of genetic evaluation eith transformed data by using damdaughter pairs of Japanese quails). Arch. Tierz., Dummerstorf 43 (2000) 3, 299-309

NARAHARI, D.; MUJEER, K. A.; THANGAVEL, A.; RAMAMURTHY, N.; VISWANATHAN, S.; MOHAN, B.; BURUNGANANDAN, B.; SUNDARARASU, V.:

Traits influencing the hatching performance of Japanese quail eggs. Br. Poult. Sci. 29 (1988) 1, 101-112

OZCELIK, M.; OZBEY O.:

The effect of the high environmental temperature on some blood parameters and the laying performance of Japanese quails with different body weights. Arch. Tierz., Dummerstorf 47 (2004) 1, 93-98

PINGEL, H.; SCHNEIDER, K.H.; VAGT, A.:

Untersuchungen über Möglichkeiten der Langzeitlagerung von Entenbruteiern. Arch. Tierz., Berlin 32 (1989) 1, 39-49

SACHDEV, A.K.; AHUJA, S.D.; THOMAS, P.C.; AGRAWAL, S.K.:

Effect of egg weight and duration storage on the weight loss, fertility and hatchability traits in Japanese quail. Indian Journal of Poult. Sci. 20 (1985) 1, 19-22

SARICA, M. ; SOLEY, F.:

The effect of hatching egg weight on the hatchability, growing and egg production traits of Japanese quail (Coturnix coturnix japonica). Journal of Agriculture Faculty of O.M.U. 10 (1995) 3, 19-30

SCHOLTYSSEK, S. Geflügel. Verlag Ulmer, Stuttgart, 1987

SCOTT, T.A.; MACKENZIE, C.J.: Incidence and classification of early embryonic mortality in broiler breeder chickens. Br. Poult. Sci. 34 (1993), 459-470

SERGEEVA, A.:

The incubation of eggs of different weight classes. Poult. Abstr. 10 (1984) 4, 542

SHAHIN, K.A.; SHEMEIS, A.R.; ABDALLAH, O.Y.; SALEH, K.:

Selection index alternatives for increases marketing, body weight with minimum concomitant reduction in body bone percentage-recourse to tissue dissection on Japanese quail. Arch. Tierz., Dummerstorf 43 (2000) 5, 535-543

SHANAWANY, M. M.:

Interrelationship between egg weight, parental age and embryonic development. Br. Poult. Sci. 25 (1984), 449-455

SNEDECOR, G.W.; COCHRAN, W.G.:

Statistical method. Seventh edition. The Iowa State University Press, Ames, Iowa, U.S.A. (1980)

SPSS FOR WINDOWS.

Release 9.0. Standard version. Copyright SPSS Inc. (1999)

SREENIVASAIAH, P.V.; RAMAPPA, B.S.: 
Influence of mating ratio and pre-incubation storage on fertility and hatchability of Japanese quail eggs. World Review of Animal Production. 21 (1988) 3-5, 25-28

SUKSUPATH, S.; TANPIPAT, S.:

Improvement of the storage methods for Japanese quail eggs before hatching. Khon Kaen Agriculture Journal. 19 (1991) 3, 156-162

UDDIN, M.S.; PAUL, D.C.; HUQUE, Q.M.E. :

Effect of egg weight and pre-incubation holding periods on hatchability of Japanese quail eggs in different seasons. Asian-Australasian Journal of Animal Sciences. 7 (1994) 4, 499-503

WILSON H. R.:

Interrelationships of egg size, chick size, post hatching growth and hatchability. World's Poultry Sci. J. 47 (1991), 5-20

YANNAKOPOULOS, A. L.; TSERVENI-GOUSI, A. S.:

Relationship of parent's age, hatching egg weight, and shell quality to day-old weight as influenced by oviposition time. Poult. Sci. 66 (1987), 829-833

Received: 2004-08-25

Accepted: 2005-09-01

Corresponding Author

Dr. İBRAHIM SEKER

Department of Zootechny, Faculty of Veterinary Medicine, Firat University, 23119 ELAZIG, TURKEY

E-mail: iseker@firat.edu.tr, iseker52@hotmail.com 